\title{
Operationalizing the role of trust for student wellbeing, learning and achievement
}

\author{
Jacqueline P. Leighton · Paolina Seitz - Man-Wai Chu - Maria Clara Bustos Gomez
}

\begin{abstract}
This paper provides an argument regarding the importance of relational trust between students and teachers during the learning process. Establishing this trust is expected to foster student wellbeing and lead to openness to learn and increased innovativeness. However, there is a relative dearth of theoretical and empirical literature on behaviors to establish relational trust (Bryk \& Schneider, 2002; Tschannen-Moran \& Hoy, 1997), and how these behaviors can be expected to lead to wellbeing and academic achievement. The Learning Errors and Formative Feedback (LEAFF) model is proposed to organize key aspects of the theoretical literature as they might relate to measurable ways in which trust can be promoted with specific words and actions in the classroom to enhance learning. Based on the LEAFF model, a framework is designed to operationalize facets of trust to help teachers develop trusting relationships with their students. However, the potential effects of these facets need to be empirically tested in future studies to secure optimal learning outcomes.
\end{abstract}

Keywords: pedagogical alliance, LEAFF model, student achievement, student wellbeing, trust

\section{Introduction}

Public education over the past several decades has been criticized for failing to maintain standards and even improve the learning outcomes of students. A reading of the literature on school reform does not only indicate failures related to students' behavioral outcomes but also points repeatedly to underlying social-emotional factors associated with this lackluster performance. Contributing factors include weakened trust, and low levels of collaboration and mutual respect in the classroom between students and teachers (Maeroff, 1993; Royal \& Rossi, 1997; Sergiovanni, 1992). Trust, in particular, is a core component of successful collaboration, respect and learning in schools but there is lack of understanding of what trust entails and its implementation within learning environments such as the classroom (Lee, 2005). Part of the challenge with understanding what is meant by trust in the classroom is that trust, as a construct, has many angles or components and is therefore difficult to define (Hoy \& Tschannen-Moran, 1999). Although, intuitively, people can identify trusting and non-trusting relationships, formally identifying the components or facets of trusting relationships and implementing these facets is more challenging. Harvey and Drolet (1994, p. 18) state it well: "Trust is much like love - we know it when we see it, but we are not sure what creates it."

We propose that the student-teacher trust relationship is a critical part of the learning process, as it fosters student wellbeing, leading to openness to learn and experimenting with ideas. Learning is an emotional, social, and profoundly collaborative process (Leighton, Chu, \& Seitz, 2013). Without trust it is difficult to imagine students and teachers collaborating towards mutual 
learning goals. Learning that is high-level and innovative must be grounded within a trusting student-teacher relationship for students to feel a sense of wellbeing - that is, the experience of safety, ability to take risks, expressing new ideas, making mistakes in the process of acquiring newly learned knowledge and skills, and developing the confidence and self-efficacy to accept feedback from teachers. Indeed, it is often reported that schools that have made significant learning gains show the presence of mutual wellbeing, based on positive and trusting relationships within a learning community (Sebring \& Bryk, 2000). More specifically, in schools where trust and cooperation exist, students report a greater sense of safety, with teachers caring about them, and consequently demonstrate greater academic achievement (Sebring \& Bryk, 2000).

Our aim in this paper is to propose the Learning Errors and Formative Feedback (LEAFF) model as a way to organize key aspects of the theoretical literature on trust and student learning. Based on the LEAFF model, a framework is designed to operationalize facets of trust to help teachers - with specific words and actions - develop trusting relationships with their students. It is our expectation that operationalizing these facets will lead to empirical work to test their effects. Therefore, this paper is distinct from other publications (e.g., Moore, 2009; Watson \& Ecken, 2003) that might provide a general listing of "things to do or consider" to achieve trust in the classroom without elaborating on specific behaviors to implement and the need to test these recommended practices. Although these publications have a place in the literature, they do not provide an analytical lens with which to examine trust - as a measured construct - and how it can begin to be empirically implemented and thus studied in the classroom. Further, this paper is distinct from other work that has focused on trust between school officials or professionals (e.g., Hoy \& Tschannen-Moran, 1999; Hoy, 2002), as our goal is to examine the role of trust between students and teachers in the classroom in the creation of student wellbeing for learning and achievement. Although there are studies that address the trusting relationships between teachers and parents, teachers and teachers, and teachers and principals, few studies focus on the relationship between students and teachers (Hoy \& Tschannen-Moran, 1999). In fact, in Trust in Schools: A Core Resource for Improvement, Bryk and Schneider (2002) point out that relational trust in schools is an undervalued and understudied topic. Meier (1995) indicates that explaining how and why some schools succeed in establishing relational trust among students and teachers is a neglected topic.

The rest of the paper is focused on providing a targeted review of the relevant literature related to the construct of trust, identifying its key facets in its relationship to wellbeing for learning and achievement, including assessment activities in the classroom, and showing how it may be behaviorally operationalized in the classroom. Further, we present a framework that specifies for teachers the words and actions that reflect facets of trust and can be expected to generate a sense of wellbeing to enhance learning and achievement in students. The paper is divided as follows: section 1 presents a targeted review of the educational and psychological literature on trust, including key facets, and why it is viewed as an essential ingredient in student wellbeing for learning and achievement. Section 2 outlines the LEAFF model and describes how trusting student-teacher relationships are the antecedent to the creation of student wellbeing for learning and achievement, including uptake of formative feedback, and assessment performance. In this second section, specifically, we explain the logical connections between the environment in which learning takes place and the mental models students build of their learning environment as they actively decide on their actions for learning. Section 3 builds on the literature review and the LEAFF model by presenting a working definition of trust and organizing key theoretical and empirical findings into a framework of how an instructor (teacher) 
might use words and actions to create trust, and student wellbeing for learning and achievement. In this third section, we focus on the role of communication as central to building trust, and the importance of congruency among words and actions. Section 4 presents a discussion and conclusion with areas of focus for future empirical research.

\section{Trust as a precursor to student wellbeing for learning and achievement}

Definitions of trust abound in the popular and social scientific research literature. According to the Merriam-Webster online dictionary (www.merriam-webster.com/dictionary), trust can be defined as the "assured reliance on the character, ability, strength, or truth of someone or something." Some definitions even include metaphorical perspectives, for example, conceptualizing trust as a type of glue that holds relationships together (Bennis \& Nanus, 1985; Rosen \& Brown, 1996). Bennis and Nanus (1985, p. 43) define, trust as "the lubrication that makes it possible for organizations to work." The message conveyed in these descriptions is that trust is essential for effective relationships. Further, it is through trust that people bond together to create meaningful interactions and overall wellbeing. More explicitly, Maister, Green and Galford (2000, p. 26) state that: "Trust is about reciprocity: you help me and I'll help you." However, although popular or metaphorical definitions are lyrical and attractive to consider, they are not helpful in facilitating a systematic understanding of a construct, as they often explain the construct (e.g., trust) with other, equally difficult to define constructs (e.g., strength and ability). For example, the Merrian-Webster definition includes terms such as reliance, character, ability and strength and even the Maister et al. (2000, p. 26) definition involves reciprocity. But these definitions do not necessarily specify measurable aspects for any of these terms.

Even educational and psychological definitions of trust are not always helpful in furthering our understanding of a multi-faceted construct such as trust. For example, Deutsch (1973) defined trust as the confidence that one will find what is desired from another rather than what is feared. Rotter (1980) expanded on this definition by stating that trust is the expectation that another's word, promise, or statement can be relied upon - which can help create a sense of wellbeing. The challenge with these definitions is that they may be overly narrow. Although trust is viewed as a fundamental element of positive relationships and is considered essential in a learning environment (Deutsch, 1958; Kosfeld, Heinrichs, Zak, Fischbacher, \& Fehr, 2005), operational definitions for how to establish and measure trust in learning environments are lacking. What is needed, then, is a definition of trust that breaks it down into more basic facets that can, in turn, be operationalized and empirically measured. One does find approximations of such a definition in the social scientific literature. For example, defining trust as a judgment that expected behaviors and actions will be executed successfully by individuals according to some criteria begins to approximate the precision of what is needed to understand trust more concretely. The purpose of this section is to provide a targeted review of the educational and psychological literature on trust in order to offer a definition that guides establishing trust for student wellbeing, learning and achievement in classroom or educational settings. Thus, this section does not provide a comprehensive treatment of trust but focuses on reviewing relevant literature pertaining to defining and building trust for student wellbeing for learning and achievement.

Trust is a multi-part construct and therefore difficult to define and operationalize (Simpson, 2007). Nonetheless it is considered vital in the process of creating meaningful human relationships. According to Bowlby (1969) trust may be the most important element in the development and maintenance of healthy and happy relationships, ultimately leading to the development and maintenance of wellbeing. Bryk and Schneider (2002) used the term "relational 
trust" to describe the interactions that take place in school settings. Bryk and Schneider (2002) state that relational trust is developed through ongoing daily interactions as everyone works together to improve learning. They view trust as a dynamic concept that is based on many factors, including respect, personal regard, competence, and personal integrity (Bryk \& Schneider, 2002). These factors are interdependent and help create the conditions for both personal and collective wellbeing, where school officials can rely on each other to fulfill their responsibilities. Satisfaction results when the groups have a shared understanding of their roles and believe each other to be acting with good intentions (Bryk \& Schneider, 2002). The development of relational trust is also based on several other factors, including the personalities of each staff member, shared values, moods, school processes, and the stage of the relationship (Tschannen-Moran, 2004). The development of relational trust among the adults in a school community is essential to student learning and achievement (Barth, 2001; Bryk \& Schneider, 2002; Hoy and Tschannen-Moran, 2003). Although in some cases trust may be initially and easily established (e.g., in therapeutic settings, see Horvath, 2000), it is not always easily obtained nor given, and it must be maintained on an ongoing basis (Meier, 2002).

In one of the few recent and comprehensive reviews on trust, Hoy and Tschannen-Moran (1999; see also Hoy \& Tschannen-Moran, 2003; Tschannen-Moran, 2004) examined the conditions associated with establishing trust. They found that a common condition for establishing trust is the willingness for individuals to risk vulnerability, that is, for two individuals to perceive that the other is willing to take a chance in losing something. In addition, in studying people or groups where trust is identified as present, Hoy and Tschannen-Moran (2003; see also Hoy \& Tschannen-Moran, 1999) identified five facets of trusting relationships that are independent but yet interrelated and reciprocally supportive: (1) benevolence, (2) reliability, (3) competence, (4) honesty, and (5) openness.

Although Hoy and Tschannen-Moran (2003) focused their research on the facets and impact of trust on school culture, and less so on student learning and achievement, their findings reflect what might be needed in trusting human relationships generally. For example, Hoy and Tschannen-Moran (1999) explained that the first facet, benevolence, involves two parts: a consideration for the needs of the other person or group, and a willingness to support their interests. The second facet, reliability, involves positive behaviors that are consistent and predictable. The third facet, competence, refers to the skills and abilities needed to accomplish a task successfully. The fourth facet, honesty, involves the commitment to be accurate and congruent in words and actions, and to follow through on promises. Further to this fourth facet, acknowledgement of errors is a major part of showing congruency in words and actions. Finally, the fifth facet, openness, includes transparency about decisions made by means of explanation, collaboration, and timely communication (Hoy \& Tschannen-Moran, 1999; Tschannen-Moran, 2004). Additional evidence has been found in support of these five facets (Geist, 2002; Hoy, Gage \& Tarter, 2006; Kochanek, 2005; and Tschannen-Moran \& Hoy, 2000).

Trusting relationships consistently reveal a constellation of features. For example, showing vulnerability or the willingness to reveal personal weakness seems to play an important role in trusting relationships. According to another recent review on trust, Burke, Sims, Lazzara and Salas (2007) identified the following components of trusting relationships: (1) a willingness to be vulnerable (see also Mayer \& Davis, 1999), (2) positive expectations that mutual interests will be protected and promoted (see also Dirks, 2000; Mayer, Davis, \& Schoorman, 1995), and (3) a positive assessment of others' intentions, sincerity, motivations, character, reliability and integrity (see also Butler, 1991; Mayer \& Davis, 1999). Baier (1994) also points out that people who are trusted often demonstrate vulnerability or show their limitations, and may place 
something or someone they care about in someone else's care. The willingness to accept weakness and susceptibility evolves over the course of a relationship through repeated actions and a history of mutual reciprocity.

Trust has also been identified as a device that may facilitate coordination within social organizations. In relation to the classroom, teachers and students can be viewed as a type of social organization whose goal is to work productively in a predictable and safe environment, where cooperation is necessary for optimal learning and achievement. In particular, Misztal (1996) identifies three functions of trust in social organizations. First, "Trust is a device for coping with the contingency and arbitrariness of social reality" (p. 96-97). Second, "Trust is a mechanism for sustaining the predictability and regularity of the collective order" (p. 96). Third, "Trust is a device for coping with the freedom of others, and functions to foster cooperation" (p. 99). One can imagine how these functions could facilitate student wellbeing for learning and achievement. In a related study, Goddard (2003) included trust as a component of social capital for aiding academic achievement in elementary school students. Goddard collected survey data from a large sample of 2,429 students and 444 teachers in 45 elementary schools to examine social capital among students, teachers, and parents. Goddard (2003) also collected data on the values that promote academic success. The analyses showed that relational trust supported the improvement of student learning and achievement. Specifically, the study showed that trusting student-teacher (i.e., Teachers in this school trust their students) and teacher-parent relationships (i.e., Teachers in this school trust the parents) have the potential to help students achieve academic success (see also Goddard, Hoy, \& Woolfolk Hoy, 2000; Goddard, Tschannen-Moran, \& Hoy, 2001). However, student trust towards teachers was not measured. Sebring and Bryk (2000) suggested that cooperative working relationships in schools "[require] a strong base of social trust among teachers, between teachers and parents, between teachers and the principal, and between teachers and students" (p.442). We propose that one way in which trust promotes learning and achievement is through student wellbeing.

There is also evidence that trust is associated with the strategies school leaders implement to establish strong relationships with their constituents. Studies of trust in schools distinguish between principal-teacher relationships, teacher-teacher relationships, and the relationships that teachers have with parents and students (Goddard, 2003; Hoy \& Tschannen-Moran, 1999; Tschannen-Moran, 2004). Tschannen-Moran (2004) considered ways in which the presence of trust helps principals and teachers feel confident to collaborate and share decision-making responsibilities. She illustrated the attitudes and behaviors that school administrators and teacher staff members described as important for trusting relationships, for example, individuals sharing a vision, modeling, coaching, managing, and mediating. For each of these actions, Tschannen-Moran (2004) indicated that trusted leaders pay close attention to sending a congruent message through words and actions. For example, in modeling, school leaders use words that match their actions, so if punctuality is described as valuable, then the school leader shows consideration for being punctual. In coaching, school leaders recognize and demonstrate active listening. In addition, in her book, Building Trust for Better Schools, Kochanek (2005) suggests a developmental approach to school leaders who aim to build trust; for example, finding ways to communicate a vision, promoting low-risk exchanges through small group interactions, using interactions to build a sense of wellbeing (to ease feelings of vulnerability), and then creating opportunities for higher-risk interactions that lead to positive outcomes. Through these repeated exchanges, Kochanek claims that staff members build confidence in themselves and others that results in greater trusting relationships. 
Although Kochanek (2005) recommends specific strategies for leaders who aim to build trust in their schools, these strategies do not necessarily extend to teachers and students. There is generally a lack of empirical, evidence-based recommendations for creating trusting studentteacher relationships, and also for repairing school environments already plagued by a lack of trust (Louis, 2008; see also Tschannen-Moran \& Hoy, 1997). When trust is identified in the educational research literature, it is mainly presented and discussed as a keystone of effective management. This is understandable, as trust facilitates social organization, as described previously. According to Anderson and Narus (1990), groups which already have a low level of trust reveal weak methods of communication, less cooperation, and more conflict in their environments (see also Cook, Hardin, \& Levi, 2005). As groups work together in principled ways to consider, debate, and decide on objectives in a positive way, they can learn to better communicate, cooperate, and produce outcomes that lead to overall group success (Limas, 2003).

Although Rotter (1967) states that trusting others to be honest and congruent in their words and actions is an important variable in creating conditions for learning, defining trust and identifying specific ways to build trusting student-teacher relationships has been challenging. However, trust between students and teachers needs to be operationalized, otherwise it is impossible to take measures to instantiate and evaluate it in classrooms. It is unlikely that teachers can be successful in achieving their overall academic mission, that is, fostering a love of learning, positive relationships, productive communication, improved decision-making, collaboration and openness (Tschannen-Moran, 2004), without practices aimed at achieving trust with students. Although trust is described as the backbone of cooperation, necessary for social organization, and the foundation for human wellbeing, again, little empirical work has been conducted to clarify its definition, role in the learning process, how it can be implemented with specific words and actions in the classroom, and ultimately evaluated. In the next section, the LEAFF model is used to elaborate on the connections between students' trust for their teachers, impressions of their learning environments and the mental models they are likely to generate that reflect their wellbeing and anticipated learning pathways. Following this second section, we offer a definition of trust and a framework of strategies for implementing trust in learning environments for further empirical study.

\section{The Learning Errors and Formative Feedback (LEAFF) model: A pedagogical alliance of trust for student wellbeing}

This section describes the LEAFF model shown in Figure 1 below. For a comprehensive introduction and explanation of the model, the reader is referred to Leighton et al. (2013). The LEAFF model was developed from a review and synthesis of the emotional, psychological, and social factors that underlie successful learning, achievement and instruction (e.g., Black \& Wiliam, 2009, Boekaerts \& Corno, 2005; Frijda \& Mesquita, 1995; Kluger \& DeNisi, 1996; Leighton, 2009; Leighton \& Gierl, 2007, 2011; Shute, 2008). In this paper, we highlight key aspects of the model, and, specifically, the foundational role that trust plays in a pedagogical alliance teachers create with students. In this alliance, the trust bond between teachers and students provides a foundation to build learning environments where students feel a sense of wellbeing, especially in revealing their learning errors, mistakes or misconceptions as they aim to meaningfully learn complex skills. According to the LEAFF model, the comfort students have with recognizing and sharing what they do not understand is the key, because the fear of mistakes and appearing "stupid" can be a profound roadblock for learning, seeking help and being receptive to feedback. The LEAFF model recognizes the importance of the teacher's words and actions in creating an environment where students experience wellbeing. This type of setting 
also influences the development of students' mental models of learning. There are three distinct parts in the LEAFF model: the instructional climate, students' mental models of learning, that is, the affective and cognitive aspects of the classroom environment, and students' academic performance.

Figure 1. The Learning Errors and Formative Feedback (LEAFF) model

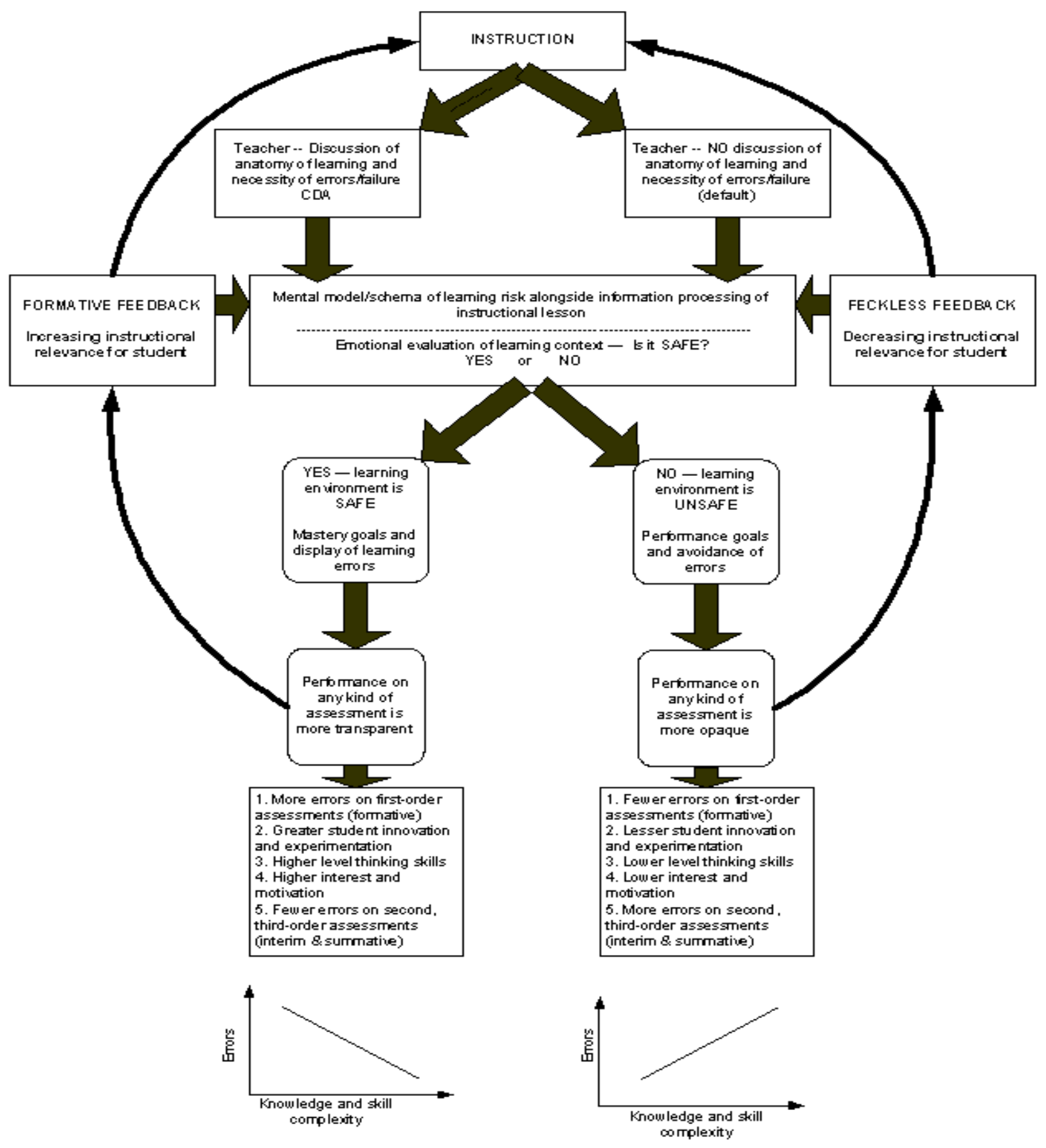

\subsection{Instructional Climate/Environment}

As shown in Figure 2 below, the first part of the LEAFF model is most pertinent to the present paper, as it focuses on the instructional climate or environment in the classroom. In this first part of the model, the teacher's words and actions can build trust, or not, with students, thus fostering either a positive or negative learning environment. Depending on the learning environment 
created, students are expected to experience varying levels of overall wellbeing for learning, which have implications for specific student behaviors, including achievement.

\section{Figure 2. First part of LEAFF model - instructional content}

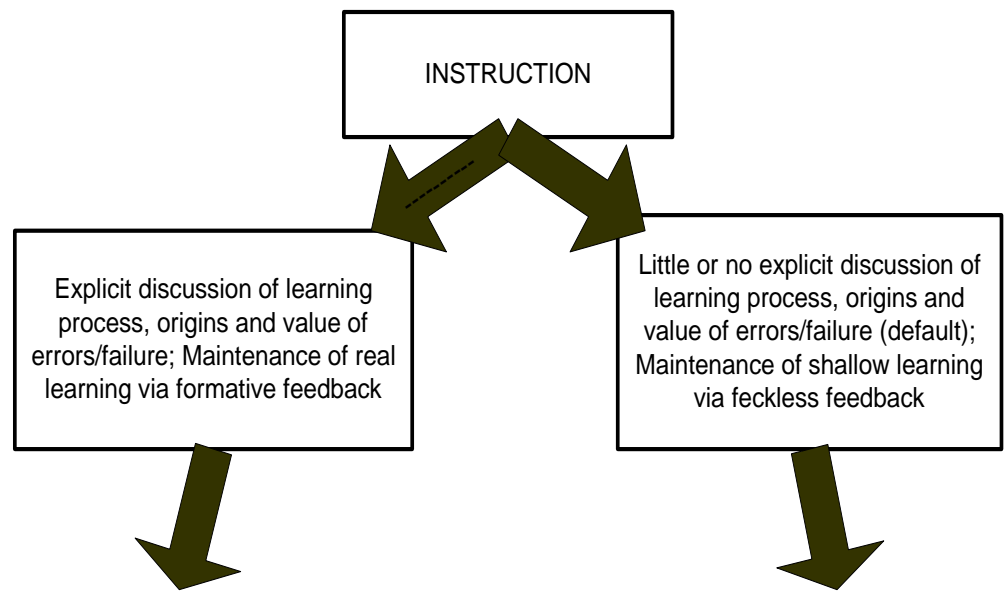

For example, in a learning environment that promotes a sense of wellbeing in students, students are expected to feel secure taking risks, to make mistakes as they learn without fear of being labeled, and show receptivity for formative feedback. In an environment that does not promote wellbeing, students are expected to feel insecure taking risks, make mistakes as they learn, and show resistance to formative feedback. The existence of trusting student-teacher relationships a pedagogical alliance - is a key part of positive learning environments where students experience wellbeing and successfully learn.

In order to develop trusting student-teacher relationships, the LEAFF model includes specific recommendations that involve explicit verbal and physical communication strategies. In particular, during instruction, teachers should verbally identify the pedagogical value of making errors as part of the learning process, and explain that it is through the understanding and correction of these errors, that student-learning gaps are addressed, leading to higher-order thinking and the advancement of learning. Further, teachers should show students the types of common errors that are often made as students acquire knowledge and skills in a particular content domain. Teachers should also demonstrate to students that teacher-led attempts to correct errors are not always successful, and repeated attempts are necessary for success. In fact, teachers should discuss the types of errors they once made as novices when they were first learning the content.

Discussing learning errors as a strategy for promoting student wellbeing is based on two facets of trust - openness and honesty (see Hoy \& Tschannen-Moran, 1999; Tschannen-Moran, 2004). Having open and honest conversations about learning errors is expected to lead students to feel relaxed about showing teachers what they do not know or what they are struggling to understand. As a result, students and teachers can feel more at ease showing vulnerability in a relationship where seeking and providing support, respectively, for learning is contingent on mutual understanding of the complexity of the learning process (see Burke et al., 2007; Mayer \& Davis, 1999). This pedagogical alliance between students and teachers involves a foundation of trust for students to show what is not understood and for teachers to help students with how to learn it. Additional strategies that are expected to build trust are presented in the next section (Wellbeing within the learning environment: A framework for defining and operationalizing trust). In addition to talking about the pedagogical value of learning errors, teachers could also 
tackle topics on the role of effort and motivation in helping students gain a deeper understanding and comfort with the many factors that influence learning. These discussions would not be expected to take place only at the beginning of a lesson plan or before assessments but during other key points in time - such as when formative feedback is administered based on interim (formative) assessment performance, and also after summative assessments.

Although teachers generally agree that making mistakes is a natural part of learning, and even understand the mistakes their students might make, there is often no explicit discussion about helping students see the value of these mistakes as opportunities for enhancing the learning process (see Leighton et al., 2013). In addition, teachers may not be cognizant of how to initiate these conversations or how to help formally establish an atmosphere of openness and honesty (Leighton et al., 2013) where trust can be cultivated and student wellbeing can take root. Students' attitudes and beliefs need to be addressed directly and overtly in the classroom in order to positively influence their feelings within the learning environment (Boekaerts \& Corno, 2005; Bransford, Brown \& Cocking, 2000; Lajoie, 2008). For example, Boekaerts and Corno (2005) indicate that student participation in classroom activities is influenced by teacher practices. These practices can bolster or undermine students' sense of wellbeing for learning.

\subsection{Mental models of learning}

The second part of the LEAFF model, shown in Figure 3 below, focuses on the perceptions or mental models students create in response to their learning environments.

Figure 3. Second part of LEAFF model - mental models of learning (including cognition and emotion)

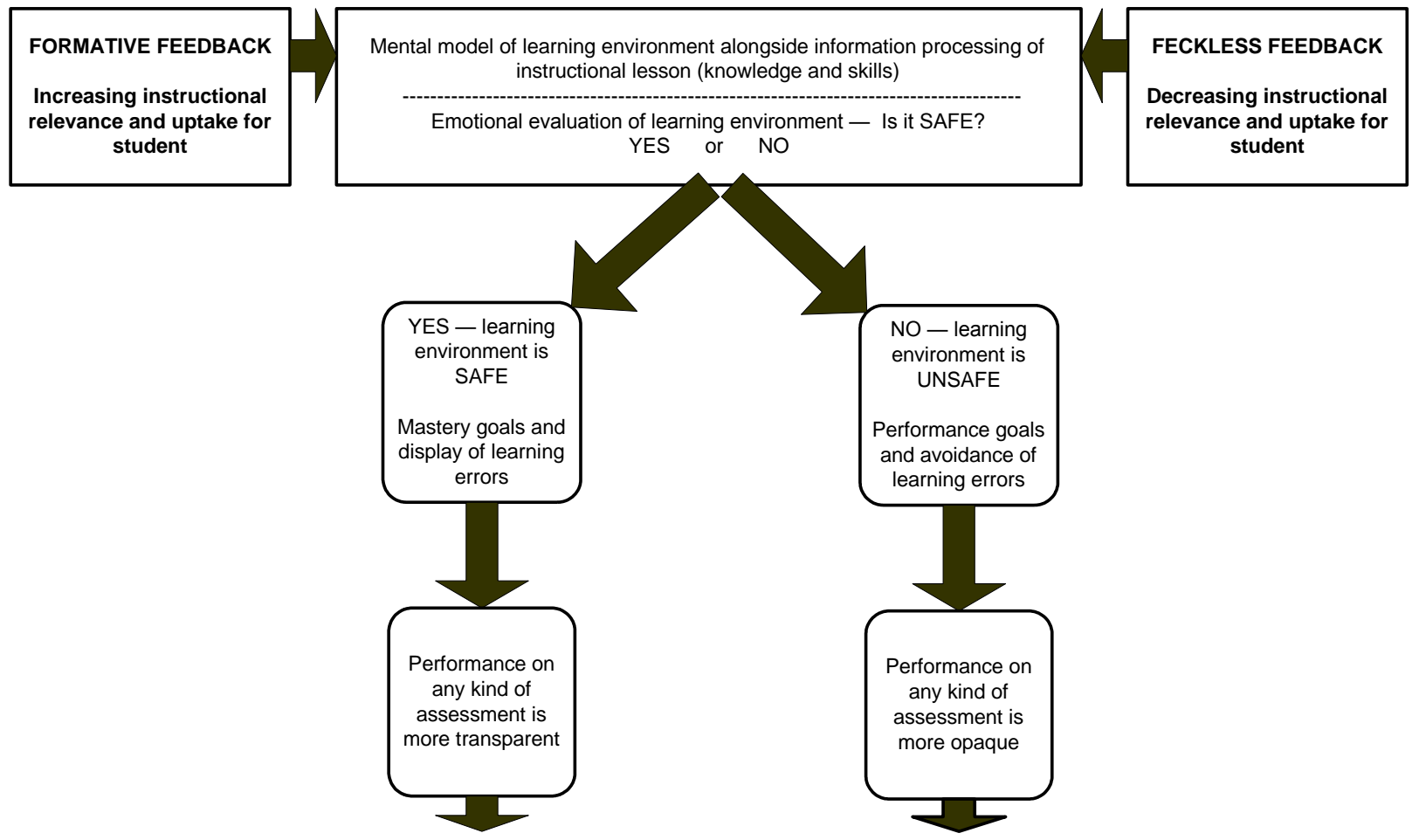

According to Johnson-Laird (2004), who has gathered significant evidence on mental models, individuals base their reasoning, problem solving and behaviors on the representations or "models" they generate of the world around them. It is expected that students base their attitudes, beliefs, and actions about learning, in part, upon the models they generate of what they 
observe and hear in their classroom environments (Leighton \& Sternberg, 2012). As illustrated in the middle box of Figure 3 above, mental models include two parts - a cognitive part related to the knowledge and skills learned in the instructional environment, and an affective part related to their sense of wellbeing within that environment (Leighton \& Sternberg, 2012). For example, on the cognitive front, a student who observes a teacher repeatedly assign math homework may add to his or her mental model the idea that math requires practicing skills. In addition, on the affective front, a student who observes a teacher constantly praise a student by saying "You always get the right answer" may develop a mental model where praise arises only from perfect responses. Associating praise from teachers only with "right answers" could lead to an excessive focus on performance, and a lack of wellbeing from feeling the pressure to avoid mistakes even in the early phases of learning complex skills. Likewise, a student who witnesses a teacher dismiss or not take personal ownership for instructional gaffes or mistakes may conclude that mistakes are denied, depending on who makes them or when they occur. Frijda and Mesquitta (1995) explain that almost all environmental events are judged to be emotionally relevant or irrelevant, positive or damaging to a particular purpose or concern.

A teacher who deliberately attempts to create a pedagogical alliance with students, namely, a safe classroom environment, by ensuring trusting student-teacher relationships, can be expected to shape students' mental models in positive ways, increase overall wellbeing, and, thus, their engagement for learning. In a safe classroom environment, students would be expected to make more mistakes initially, as they learn content material, because they are likely to feel relaxed to try things out and experiment in front of the teacher. Within a safe learning environment, students' wellbeing would be expected to lead to greater uptake of formative feedback about their performances, more innovative problem-solving strategies and greater mastery orientations toward learning. Kluger and DeNisi (1996) and Shute (2008) suggest that in order for feedback to be formative, the student must trust the teacher who delivers the information and be willing to accept and utilize the feedback. In contrast, students who emotionally evaluate the instructional context to be unsafe would be expected to act in opposite ways to students who judge the instructional context to be safe. That is, students would be expected to avoid making mistakes, as they would not want to be vulnerable in front of a teacher who is punitive about errors. Further, in an unsafe learning environment, students would be expected to develop performance orientations toward learning rather than mastery orientations, and be less willing to risk innovative thinking and problem solving. If students experience trepidation (lack of wellbeing) to show a teacher what they know or do not know, they may fail to believe that a teacher's feedback about their performance is accurate. In their meta-analysis of the role of feedback on performance, Harris and Rosenthal (1985) showed that the climate created for feedback had a greater effect on student performance than the quantity of feedback provided.

\subsection{Learning and achievement performance}

The third part of the LEAFF model, shown in Figure 4 below, focuses on student performance. Specifically, this third part indicates that students are more likely to be transparent in showing what they know or do not know on assignments and assessments when they feel a sense of wellbeing within their learning environment. When this occurs, student performance is expected to yield superior information to teachers of actual learning levels. If students view their performance on assessments, especially formative assessments, as opportunities to freely show what they do not know and receive help, they are more likely to be receptive to formative feedback as a tool for improving learning. Conversely, again based on the LEAFF model but needing empirical testing, when students feel a lack of wellbeing within their learning 
environment, and unsafe to show their misunderstandings on assignments and assessments, they are less likely to receive accurate formative feedback. This hesitance to be receptive to formative feedback is expected to occur if students fail to believe the assignment or assessment measured what they were struggling to learn.

Figure 4. Third part of LEAFF model - performance and predictions

\begin{tabular}{|l|}
$\begin{array}{c}\text { Performance on } \\
\text { any kind of } \\
\text { assessment is } \\
\text { more transparent }\end{array}$ \\
$\begin{array}{l}\text { 1. More errors on first-order } \\
\text { assessments (formative and } \\
\text { cognitive diagnostic) } \\
\text { 2. Greater student innovation } \\
\text { and experimentation } \\
\text { 3. Higher level thinking skills } \\
\text { 4. Higher interest and } \\
\text { motivation } \\
\text { 5. Fewer errors on second, } \\
\text { third-order assessments } \\
\text { (interim \& summative) }\end{array}$ \\
\hline
\end{tabular}

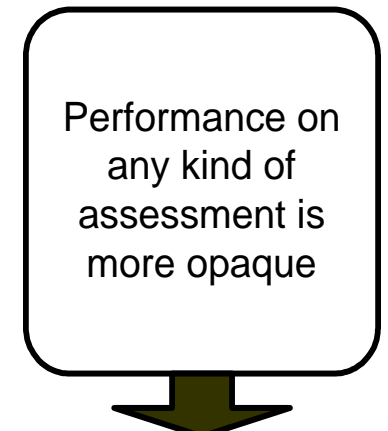

1. Fewer errors on first-order assessments (formative and cognitive diagnostic)

2. Lesser student innovation and experimentation

3. Lower level thinking skills

4. Lower interest and motivation

5. More errors on second, third-order assessments (interim \& summative)
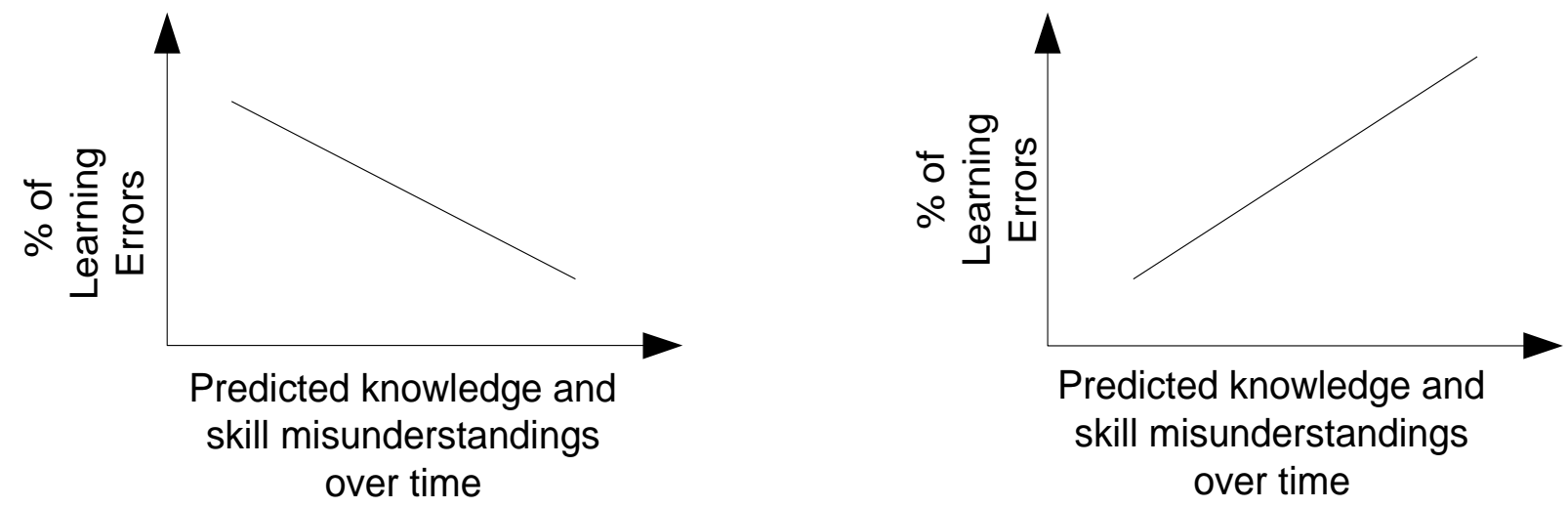

In addition, several predictions are described in Leighton et al. (2013) about students' performance when they develop mental models that include a sense of wellbeing for learning: students will initially make more learning errors on formative assessments; students will show more creativity, ingenuity, and higher-order thinking as they encounter challenging, new material and as they learn the material; students will demonstrate higher intrinsic motivation in the content area; and, over time, students will make fewer errors on summative assessments. The opposite is expected of students who develop mental models that reflect a lack of wellbeing for learning, irrespective of the strength of their mental models in terms of understanding cognitive 
skills. The LEAFF model indicates that the most important input variable to student learning and assessment is the trust between student and teacher (i.e., pedagogical alliance) and the subsequent feeling of wellbeing that is then generated within that safe learning environment. Thus, trust is expected to be a key part of developing and maintaining wellbeing within this environment (e.g., see Hoy \& Tschannen-Moran, 2003; see the section in this paper: Trust as a precursor to student wellbeing for learning).

Without trust, the mental models students create would be expected to pair the absence of wellbeing with learning, and direct them to avoid showing what they truly know (or do not know) for fear of making mistakes. Further, by not feeling at ease in demonstrating honest struggles with learning, students are unlikely to trust the accuracy of the feedback delivered to them, based on their performance on assessments. Therefore, the question we address in the next section is how to best define and operationalize trust in order to systematically and empirically study and enhance student wellbeing for learning.

\section{Wellbeing within the learning environment: A framework for defining and operationalizing trust}

Based on the previous two sections of this paper, this section provides a working definition of trust and operationalizes the construct into active strategies that teachers can implement in order to create student wellbeing in the classroom environment. As mentioned previously, trust is a complex construct (Hoy \& Tschannen-Moran, 1999, Mayer et al., 1995) with descriptions of trust often including individual perception, vulnerability, and congruency of words and action (communication). Further, Hoy and Tschannen (1999) assert that trusting relationships involve five facets: benevolence, reliability, competence, honesty and openness. Although all five facets are considered important, their individual levels of influence on the creation of a trusting relationship may vary depending on the needs of the student. In this paper we propose the following working definition of trust based on the targeted review of the educational and psychological literature, and specifically Hoy and Tschannen's (1999) five facets: Trust is experienced when an individual perceives benevolence, reliability, competence, honesty, and openness in another individual; these facets are communicated in relationships often through timely congruency of words and actions. Although this definition of trust includes additional constructs or latent variables (e.g., benevolence, reliability), we operationalize the definition into more basic and potentially measurable word and actions (strategies) as shown in the theoretical framework in Table 1 below. The framework illustrates measurable behaviors that require testing and verification with empirical studies (see Leighton \& Bustos Gomez, 2014 for an empirical demonstration).

An important feature of operationalizing trust is identifying ways to communicate with words and actions. Although teachers recognize that communication is an important element in the creation of student wellbeing for learning, few are explicitly aware of the impact of communication on their ability to build trust (Charles, 1999). Brown (2005) indicates trust begins to develop between students and teachers when teachers establish appropriate and explicit methods of communication with each student in the classroom. Communication is defined as the interaction between teachers and students before, during, and after class, and is the basis for the development of a classroom climate that includes reciprocal respect between students and teachers. In addition, this communication must be perceived as congruent (Brown, 2005). 
Table 1a. A theoretical framework for beginning to operationalize trust and create a pedagogical alliance

\begin{tabular}{|c|c|c|}
\hline $\begin{array}{l}\text { Facet of Trust } \\
\text { (Latent Variable) }\end{array}$ & Positive Behaviors, Actions, and/or Words to Implement & Negative Behaviors, Actions, and/or Words to Avoid \\
\hline $\begin{array}{l}\text { 1. Benevolence-a } \\
\text { consideration for } \\
\text { the needs of the } \\
\text { other person or } \\
\text { group, and a } \\
\text { willingness to } \\
\text { support their } \\
\text { interests }\end{array}$ & $\begin{array}{l}\text { Getting to know students in terms of their strengths and weaknesses } \\
\text { by asking them questions in a mindful and nonthreatening (kind) } \\
\text { manner such as with the following stem: All students learn in different } \\
\text { ways. I'm curious to know about your feelings and thoughts on something. } \\
\text { What do you think about this material? Example questions can include the } \\
\text { following: } \\
\text { - What content material they find difficult to understand or easy to } \\
\text { - understand and why; } \\
\text { - What they find ambiguous about content material as they } \\
\text { - complete assignments or homework; } \\
\text { - What they enjoy about school and learning and why; } \\
\text { - How they think they can best achieve their goals and where they } \\
\text { - How they feel about formative and summative assessments and } \\
\text { - Hhy; } \\
\text { - Whw they feel about receiving feedback about their work; } \\
\text { - Whe they have to focus on learning content material outside } \\
\text { of school; }\end{array}$ & $\begin{array}{l}\text { Making “know-it-all” statements suggesting you already } \\
\text { know students' strengths and weaknesses, including how } \\
\text { they think and feel about a topic is not recommended because } \\
\text { it does not properly include the learner in his or her learning. } \\
\text { The following examples provide statements that should } \\
\text { therefore be avoided: } \\
\text { - I know why you didn't complete the } \\
\text { assignment/homework; you find this difficult - don't } \\
\text { you? } \\
\text { - Sure you know this - that's right, you always know the } \\
\text { answers to questions (sarcasm); } \\
\text { - You know, you really need to stop wasting time and work } \\
\text { harder because you are going to fail this course and it } \\
\text { may be what you deserve (verbal put down); } \\
\text { - This is the way we always do things here - you hand in } \\
\text { your homework and if you don't, you get a zero (no } \\
\text { explanation; arbitrary rules); } \\
\text { - I am not going to listen anymore because none of what } \\
\text { you're saying makes sense (negative responses); } \\
\text { - Why can't you be more like Fred (or Sally) who works } \\
\text { hard and is a high achiever (comparisons and favoritism)? }\end{array}$ \\
\hline
\end{tabular}


Table $1 \mathrm{~b}$. A theoretical framework for beginning to operationalize trust and create a pedagogical alliance

\begin{tabular}{|c|c|}
\hline $\begin{array}{l}\text { Facet of Trust } \\
\text { (Latent Variable) }\end{array}$ & Positive Behaviors, Actions, and/or Words to Implement \\
\hline $\begin{array}{l}\text { 2. Reliability - } \\
\text { positive } \\
\text { behaviors/words } \\
\text { that are consistent } \\
\text { and predictable }\end{array}$ & $\begin{array}{l}\text { Depending on the teacher to come through with what is needed or } \\
\text { agreed upon; consistent follow-through with commitments by } \\
\text { showing students that you remember their questions, needs for } \\
\text { clarification, and requests for assistance. Examples of demonstrating } \\
\text { reliability include statements such as the following: } \\
\text { - Here is the information for the question you asked for a couple of } \\
\text { days ago. I'm sorry it took me a couple of days to get back to you; } \\
\text { - Let's clarify what is needed for this lesson so that we are all on the } \\
\text { same page and there are no misinterpretations; } \\
\text { - Please help me understand the kind of information you think } \\
\text { - would be helpful in learning this concept (skill, idea); } \\
\text { The test that you are about to complete reflects the concepts and } \\
\text { skills that we have talked about and learned in class. If you don't } \\
\text { agree, please let me know after class. }\end{array}$ \\
\hline
\end{tabular}

\section{Negative Behaviors, Actions, and/or Words to Avoid}

Demonstrating inconsistency and apathy - either explicitly or implicitly - is to be avoided. The following statements are examples of potential responses that likely reflect problems prioritizing a student's needs and follow through:

- I'm sorry I'm so late with this information but I forgot you needed it... can you still use it given that it is so late?

- I forgot and I'm not prepared to answer your question (or help you learn the material);

- I am disorganized with my papers. Where did I leave my responses to your questions?

- I recognize that I am changing things from what is stated in the course outline (syllabus) but I think what we are doing now is more important....;

- I am sorry for returning this assignment late with my feedback. I got busy with other things;

- That is a great question but I can't answer it right now because we need to move on to the next assignment. 
Table 1c. A theoretical framework for beginning to operationalize trust and create a pedagogical alliance

\begin{tabular}{ll}
\hline $\begin{array}{l}\text { Facet of Trust } \\
\text { (Latent Variable) }\end{array}$ & Positive Behaviors, Actions, and/or Words to Implement \\
\hline $\begin{array}{l}\text { 3. Competence - } \\
\text { skills and } \\
\text { abilities needed } \\
\text { to accomplish a } \\
\text { task successfully }\end{array}$ & $\begin{array}{l}\text { Having the explicit, demonstrable knowledge and skills necessary the } \\
\text { perform the role of teacher. Furthermore, having the softer skills } \\
\text { associated with character, integrity, and authenticity that enables } \\
\text { effective use of domain knowledge and skills for a teacher to be } \\
\text { effective. Example actions that indicate teachers possess compete } \\
\text { necessary skills include: }\end{array}$ \\
& $\begin{array}{l}\text { Spending time during the day to find out how students learn } \\
\text { (asking questions and observing), what difficulties they are } \\
\text { having, and designing lessons and tasks that correspond to } \\
\text { students' styles; }\end{array}$
\end{tabular}

- Showing understanding of the content material, attempts to make instruction interesting (experimenting with delivery), and not being afraid to acknowledge what is not known (demonstrate to students that an expert sometimes also makes learning errors);

- Showing positive and constructive attitude towards learning and in light of students' questions - using statements such as That is a great question... or That is a great answer but not for this question...;

- Knowing how to develop lesson plans and participating in professional development;

- Providing kind, high-quality feedback that is specific and formative in indicating what the student needs to do to achieve the next level of expertise and developing a plan with the student to help the student achieve the next level;

- Providing constant opportunities for students to take part in learning and demonstrations of learning - such as Let's try to show what we have learned in this new area...;

- Managing classroom environment to be positive, respectful, and constructive.

\section{Negative Behaviors, Actions, and/or Words to Avoid}

Demonstrating continued ineffectiveness or lack of understanding via actions, and not addressing lack of knowledge or skill in teaching. Continued ineffectiveness sends a message to students that the teacher does not care to improve and thus may not care about their learning. Example behaviors that demonstrate ineffectiveness can include:

- Not knowing how to answer students' questions about content material and not following up the next day with answers (e.g., I'm not sure why you don't understand this; and I'm not sure how to help anymore);

- Lacking professionalism with inappropriate use of grammar, voice, and treatment of students at all times in and out of school settings (e.g., using sarcasm to tease a student about being late for class but never for recess);

- Appearing confused in the middle of a lesson and then not owning up to the reason for confusion;

- Providing unclear instructions for assignments or assessments, not clarifying comprehensively when students ask questions;

- Creating assessments that students perceive as unfair and not discussing or explaining rationale for assessment;

- Providing excessive information during lesson and not demonstrating sensitivity to students' learning states. 
Table 1d. A theoretical framework for beginning to operationalize trust and create a pedagogical alliance

\begin{tabular}{|c|c|c|}
\hline $\begin{array}{l}\text { Facet of Trust } \\
\text { (Latent Variable) }\end{array}$ & Positive Behaviors, Actions, and/or Words to Implement & Negative Behaviors, Actions, and/or Words to Avoid \\
\hline $\begin{array}{l}\text { 4. Honesty - } \\
\text { commitment to be } \\
\text { truthful and to } \\
\text { follow through on } \\
\text { promises; } \\
\text { acknowledgement } \\
\text { of errors and } \\
\text { demonstrating } \\
\text { congruency } \\
\text { between what is } \\
\text { intended, said } \\
\text { and done }\end{array}$ & $\begin{array}{l}\text { Showing character, integrity, and authenticity, and demonstrating } \\
\text { congruency in intentions, words, and actions. Honesty also entails } \\
\text { accepting responsibility for mistakes or events that have gone awry } \\
\text { because of teacher's words or actions. Examples of showing honesty } \\
\text { include: } \\
\text { - Admitting when a mistake has been made during a lesson or some } \\
\text { other activity and indicating a willingness to correct it; } \\
\text { - Admitting when something (knowledge or skill) is not known, } \\
\text { being willing and able to find out the answer, and getting back to } \\
\text { a student in a timely manner; } \\
\text { - Creating assessments that correspond to what is being taught in } \\
\text { the classroom and not surprising students; } \\
\text { - Being able to laugh at oneself during moments of not knowing, } \\
\text { making a mistake or when a student points out a mistake; } \\
\text { - Modeling nature of learning by thinking out loud in front of } \\
\text { students in a clear way so that students see and hear how an } \\
\text { expert frames knowledge and skills, and observe the recursive } \\
\text { ways in which learning takes place; } \\
\text { - Explaining to students during lessons and discussion that errors } \\
\text { and mistakes are a part of the learning process; } \\
\text { - Allowing students equal opportunity and time to participate in } \\
\text { class discussions, answer questions, commenting on ideas; } \\
\text { Ensuring that promises made to students are kept - whether it is } \\
\text { in terms of finding out information or doing something for a } \\
\text { lesson plan. }\end{array}$ & $\begin{array}{l}\text { Lacking congruency in intentions, words and actions indicate } \\
\text { to students that teachers are not reliable and therefore may } \\
\text { not be trustworthy; unpredictability can lead to teachers } \\
\text { being viewed as dishonest. Examples of actions to avoid } \\
\text { include: } \\
\text { - Discussing the naturalness of making errors in the } \\
\text { learning process but then not acknowledging errors if } \\
\text { they are committed during teaching; } \\
\text { - Failing to keep promises - telling a student that you will } \\
\text { find the answer to a question raised during a lesson and } \\
\text { then forgetting to find the answer; } \\
\text { - Being incongruent in intentions, words, and actions - } \\
\text { talking about the importance of fair testing and } \\
\text { administering assessments that measure material not } \\
\text { covered in class. }\end{array}$ \\
\hline
\end{tabular}


Table 1e. A theoretical framework for beginning to operationalize trust and create a pedagogical alliance

\begin{tabular}{|c|c|c|}
\hline $\begin{array}{l}\text { Facet of Trust } \\
\text { (Latent Variable) }\end{array}$ & Positive Behaviors, Actions, and/or Words to Implement & Negative Behaviors, Actions, and/or Words to Avoid \\
\hline $\begin{array}{l}5 . \text { Openness - } \\
\text { being transparent } \\
\text { about the } \\
\text { decisions made } \\
\text { by being } \\
\text { collaborative and } \\
\text { providing timely } \\
\text { communication }\end{array}$ & $\begin{array}{l}\text { Being willing and able to share relevant information with students so } \\
\text { that transparency is achieved. Examples of words and actions that } \\
\text { demonstrate openness include: } \\
\text { - Providing a rationale or reason for disciplining a student clearly } \\
\text { so that a student understands the precise connection between } \\
\text { behavior and consequence (e.g., I need to ask you to move from this } \\
\text { table because this environment is not helping you concentrate on the } \\
\text { task);" } \\
\text { - Stating and explaining expectations for how to behave in class and } \\
\text { what is to be learned in the curriculum (e.g., today we are going to } \\
\text { learn how to add fractions and why adding fractions seems tricky at } \\
\text { first); } \\
\text { Providing explanations when students are behaving in } \\
\text { disappointing ways and changing expectations to improve } \\
\text { performance; } \\
\text { - Consulting with parents, following up and bringing them into } \\
\text { discussions about student learning; } \\
\text { Being explicit (clear) about expectations for learning outcomes and } \\
\text { content that will be included on formal tests; } \\
\text { Requesting anonymous feedback from students about classroom } \\
\text { instruction and being open to acting on constructive ideas; } \\
\text { Listening to students when they have concerns and questions, and } \\
\text { being inclusive of ideas about learning and direction of classroom } \\
\text { instruction. }\end{array}$ & $\begin{array}{l}\text { Avoiding opportunities to be open and lacking openness } \\
\text { sends the message to students that something inappropriate } \\
\text { may be occurring and that the teacher may not have their } \\
\text { best interests at heart. Examples of words and actions that } \\
\text { indicate lack of openness include the following: } \\
\text { - Using unclear or vague language to communicate } \\
\text { learning outcomes (course objectives) - saying "Today we } \\
\text { are going to learn about fractions" is too vague and needs } \\
\text { to be more explicit about specific concepts and skills that } \\
\text { will be tackled; } \\
\text { - Administering tests and not explaining to students the } \\
\text { objective of tests and results; } \\
\text { - Being unwilling to consider alternative methods for } \\
\text { presenting concepts (differentiated instruction) and } \\
\text { content material, being closed to feedback or student } \\
\text { opinions without explanation. }\end{array}$ \\
\hline
\end{tabular}


Teachers engage in congruent communication with students when their words and actions are aligned (Brown, 2005). Although Brown (2005) also indicates that teachers' intentions must be aligned to words and actions, intentions can only be observed and judged as congruent through words and actions. Teachers can facilitate congruency in communication by actively listening to students if they claim that they listen to students, matching their body language and facial expressions to their verbal messages, responding to students with empathy when appropriate, and avoiding communication roadblocks (Charles, 1999). In particular, active listening and body language techniques include eye contact, facing the student during dialogue, acknowledging student talking by nodding, rephrasing to check for understanding, and not interrupting the student while he or she is talking (e.g., empathic listening; see Horvath, 2000).

Roadblocks that can undermine teachers' efforts for congruent communication include comments that are negative and tend to put students down, for example, questions such as "Did you mess up again?" or moralizing statements such as "Who says that life is fair?" can discourage communication and can send students the message that their teachers are really not interested in what they say or feel. Englander (1986) called these comments "low respect" responses that impose the teachers' own values and solutions on students. Congruent communication can help instantiate the facets of trust in a classroom (Baier, 1986; Parsons, 1960) for student wellbeing.

In addition to congruent communication, Thweatt and McCroskey (1998) suggest that teachers who respond to students' needs in a timely manner can positively impact students' views about the trustworthiness of their teachers. All these positive actions begin to set the stage to build what we call a pedagogical alliance or trust bond between students and teachers. In contrast, teachers who fail to respond to students' needs in a timely manner negatively impact trustworthiness. Thweatt and McCroskey (1998) also suggest that communication techniques that mirror the instructional foci in the classroom are beneficial to building desired levels of trust. For example, creating a supportive rapport (e.g., encouraging students to not lose confidence when they get the wrong answer) when instructing students can help them learn to see the teacher as someone who has their best interest in mind. Further, it is important to recognize that teacher-student relationships are continuous, with interactions occurring on a daily basis. This relational continuity serves as an incentive to behave in trustworthy ways and to reap the benefits of trusting relationships (Hoy \& Tschannen-Moran, 1999).

The proposed framework shown in Table 1 above shows the five facets outlined by Hoy and Tschannen-Moran (1999) in the first column. The facets are comprehensive and supported by additional research in the social sciences (e.g., Schoorman, Mayer, \& Davis, 2007). Although some have suggested that trust may have as few as three facets or as many as ten (Butler, 1991; Bryk \& Schneider, 2002), the five facets outlined in Hoy and Tschannen-Moran align with additional research on effective and congruent communication techniques conducive to building a pedagogical alliance or trust bond in the classroom. These five facets are latent variables that need to be operationalized with measurable words and actions. The second column outlines behavioral examples - the words and actions - that we consider to operationalize the latent variables. The third column outlines examples of words and actions that are opposite to those listed in the second column; these words and actions are expected to create obstacles to building trust in the classroom (i.e., pedagogical alliance).

As shown in Table 1 above, one of the first facets for creating trusting relationships involves benevolence. In the second column, specific behaviors are listed for demonstrating benevolence, in particular, the importance of asking questions and getting to know students, taking time to listen, expressing an interest in understanding their perspective, and interacting with students. Along with lesson plans, teachers could build specific opportunities for asking questions to find 
out about students' perspectives about the material, including what they find irrelevant or difficult. These moments of asking questions create opportunities for open dialog that may help students see their teachers as caring individuals interested in students' perspectives and provide channels for deeper learning. Additional facets of Table 1 above can be interpreted in a similar manner.

Implementing words and actions that operationalize trust should be done continuously during formal and informal time spent with students. For example, demonstrating the second facet of reliability can be done formally when a new lesson is introduced and students raise questions that require follow-up, based on further investigation (e.g., "That is a great question that I cannot answer at this very moment but let me find out the answer and get back to you"). Reliability can also be demonstrated when reviewing assessment results with students. In these situations, if a teacher is helping to explain a missed concept and fails, coming back to the concept and attempting to explain it again using new methods is instrumental (e.g., "I am finding that this approach is not working well to help explain division of fractions, so let me find another way and we'll try again tomorrow"). The guiding mandate for teachers who wish to convey reliability is to show students that they can be relied on to listen to students' questions, needs for clarification, and requests for assistance, even if traditional methods fail and new methods must be sought. As another example, demonstrating the fourth facet, honesty, can be done at the beginning of a new lesson. Honesty can be modeled by discussing the value of making learning errors in the acquisition of new knowledge and skills (e.g., "I am going to tell you a secret mistakes are a natural part of learning something new..."). Honesty can also be woven into the feedback provided to students about their mistakes as they attempt to conquer new concepts (e.g., "See this mistake right here - this is an important mistake to make; you should feel proud of this mistake, as it indicates that you have grasped a high-level concept that you are trying to overgeneralize... but incorrectly").

\section{Discussion and conclusion}

In this paper we proposed that student wellbeing for learning and achievement is promoted by the construct of trust between student and teacher, and its operationalization within a classroom environment. We called this trust bond the pedagogical alliance. Trust was identified as the key element in building student-teacher relationships in order to support meaningful, innovative student learning. We began this paper by providing a targeted review of the literature indicating that trust is a multi-faceted construct. Five facets of trusting relationships were highlighted benevolence, reliability, competence, honesty, and openness - as discussed in the work of Hoy and Tschannen-Moran (1999). We offered ways to operationalize these five facets (see Table 1 above) in order to make explicit the words and actions that can be implemented in order to build trust in student-teacher relationships and then measure their effects. The role of congruent communication was also explained as central to building and operationalizing trust.

The current research literature discusses the importance of trusting relationships among the adults in the school community. But there is a significant shortfall in the discussion of trusting relationships between students and teachers in classrooms, especially in terms of how specifically to build trust. Although the five facets of trust (Hoy \& Tschannen-Moran, 1999) are grounded in the research literature, these five facets require further understanding and empirical testing. For example, research is needed to examine the extent to which the five facets of trust when operationalized into behaviors and learning interventions - actually build trust in the classroom (however, see Leighton \& Bustos Gomez, 2014 for empirical work). We need to gain a better understanding of how congruent communication influences the five facets of 
benevolence, reliability, competence, honesty, and openness. To begin to formalize ways in which we can help teachers and students develop trusting relationships for student wellbeing, a framework that operationalized the five facets of trust was outlined in Table 1 above. This framework is designed to help teachers implement the five facets of trust in their classroom with students. If trust is assumed to be a prerequisite condition for student wellbeing for learning and achievement, as we have articulated it is, then being able to operationalize these five facets of trusting relationships to build a pedagogical alliance is necessary to evaluate their role in learning and assessment processes occurring in the classroom. Our next goal is to conduct empirical studies that test the effects of these five facets of trusting relationships for creating safe environments where learning and assessment practices are maximized for student wellbeing and academic success.

\section{Acknowledgments}

Preparation of this paper was supported by a grant to the first author from the Social Sciences and Humanities Research Council of Canada (SSHRC Grant No. 410-2011-0811). Grantees undertaking such projects are encouraged to express freely their professional judgment. This paper, therefore, does not necessarily represent the positions or the policies of the Canadian Government, and no official endorsement should be inferred. Questions related to this paper should be directed to the first author by contacting jacqueline.leighton@ualberta.ca.

\section{Authors}

Jacqueline P. Leighton

University of Alberta

jacqueline.leighton@ualberta.ca

Paolina Seitz

St. Mary's University

Man-Wai Chu

University of Calgary

Maria Clara Bustos Gomez

Colegio Gimnasio Los Pinares

\section{Publishing Timeline}

Received 10 Septmeber 2015

Accepted 24 April 2016

Published 14 September 2016

\section{References}

Anderson, J. C., \& Narus, J. A. (1990). A model of distributor firm and manufacturer firm working partnerships. Journal of Marketing, 54(1), 42-58. http://dx.doi.org/10.2307/1252172

Baier, A. (1986). Trust and antitrust. Ethics, 96(2), 231-260. http://dx.doi.org/10.1086/292745

Baier, A. (1994). Moral prejudices: Essays on ethics. Cambridge, MA: Harvard University Press.

Barth, R. (2001). Learning by heart. San Francisco, CA: Jossey-Bass.

Bennis, W., \& Nanus, B. (1985). Leaders: The strategies for taking charge. New York, NY: Harper \& Row.

Black, P., \& Wiliam, D. (2009). Developing the theory of formative assessment. Educational Assessment, Evaluation, and Accountability, 21(5), 5-31. http://dx.doi.org/10.1007/s11092-008-9068-5 
Boekaerts, M., \& Corno, L. (2005). Self-regulation in the classroom: A perspective on assessment and intervention. Applied Psychology: An International Review, 54(2), 199-231. http://dx.doi.org/10.1111/j.1464-0597.2005.00205.x

Bowlby, J. (1969). Attachment and loss (Vol. 1). New York, NY: Basic Books.

Bransford, J., Brown, A., \& Cocking, R. (2000). How people learn: Brain, mind, experience, and school: Expanded Edition. Washington, DC: National Academy Press.

Brown, D. (2005). The significance of congruent communication in effective classroom management. Journal of Educational Strategies, Issues and Ideas, 79(1), 12-15. http://dx.doi.org/10.3200/TCHS.79.1.12$\underline{15}$

Bryk, A., \& Schneider, B. (2002). Trust in schools: A core resource for improvement. New York, NY: Russell Sage Foundation.

Burke, C., Sims, D., Lazzara, E., \& Salas, E. (2007). Trust in leadership: A multi-level review and integration. The Leadership Quarterly, 18(6), 606-632. http://dx.doi.org/10.1016/j.leaqua.2007.09.006

Butler, J. (1991). Towards understanding and measuring conditions of trust: Evolution of a conditions of trust inventory. Journal of Management, 17(3), 643-663. http://dx.doi.org/10.1177/014920639101700307

Charles, C. (1999). Building classroom discipline (6th ed.). New York, NY: Addison Wesley and Longman.

Cook, K., Hardin, R., \& Levi, M. (2005). Cooperation without trust. New York, NY: Russell Sage.

Dirks, K. (2000). Trust in leadership and team performance: Evidence from NCAA Basketball. Journal of Applied Psychology, 85(6), 1004-1012. http://dx.doi.org/10.1037/0021-9010.85.6.1004

Deutsch, M. (1958). Trust and suspicion. Journal of Conflict Resolution, 2, 265-279. http://dx.doi.org/10.1177/002200275800200401

Deutsch, M. (1973). The resolution of conflict. New Haven, CT: Yale University Press.

Englander, M. E. (1986). Strategies for classroom discipline. New York, NY: Praeger.

Frijda, N., \& Mesquita, B. (1995). The social roles and functions of emotions. In S. Kitayama \& H. Markus (Eds.), Emotion and culture (pp. 51-88). Washington DC: American Psychological Association.

Geist, J. (2002). Predictors of faculty trust in elementary schools: Enabling bureaucracy, teacher professionalism, and academic press. (Unpublished doctoral dissertation). Ohio State University, Columbus, $\mathrm{OH}$.

Goddard, R. (2003). Relational networks, social trust, and norms: A social capital perspective on students' chances of academic success. Educational Evaluation and Policy Analysis, 25(1), 59-74. http://dx.doi.org/10.3102/01623737025001059

Goddard, R., Hoy, W., \& Woolfolk Hoy, A. (2000). Collective teacher efficacy: Its meaning, measure, and impact on student achievement. American Educational Research Journal, 37(2), 479-507. http://dx.doi.org/10.3102/00028312037002479

Goddard, R., Tschannen-Moran, M., \& Hoy, W. (2001). A multilevel examination of the distribution and effects of teacher trust in urban elementary schools. Elementary School Journal, 102(1), 3-17. http://dx.doi.org/10.1086/499690

Harris, M., \& Rosenthal, R. (1985). Mediation of interpersonal expectancies effects: 31 meta-analyses. Psychological Bulletin, 97(3), 363-386. http://dx.doi.org/10.1037/0033-2909.97.3.363

Harvey, T., \& Drolet, B. (1994). Building teams, building people: Expanding the fifth resource. Lanham, MD: Rowman \& Littlefield.

Horvath, A. O. (2000). The therapeutic relationship: From transference to alliance. Psychotherapy in Practice, 56(2), 163-173.

Hoy, W. (2002). Faculty trust: A key to student achievement. Journal of School Public Relations, 23(2), 88103.

Hoy, W., Gage, C., \& Tarter, C. (2006). School mindfulness and faculty trust: Necessary conditions for each other? Educational Administration Quarterly, 42(2), 236-255.

http://dx.doi.org/10.1177/0013161X04273844

Hoy, W., \& Tschannen-Moran, M. (1999). Five faces of trust: An empirical confirmation in urban elementary schools. Journal of School Leadership, 9(3), 184-208.

Hoy, W., \& Tschannen-Moran, M. (2003). The conceptualization and measurement of faculty trust in schools. In W. Hoy \& C. Miskel (Eds.), Studies in leading and organizing schools (pp. 181-207). Greenwich, CT: Information Age. 
Johnson-Laird, P. (2004). Mental models and reasoning. In J. P. Leighton \& R. J. Sternberg (Eds.), The nature of reasoning (pp. 169-204). New York, NY: Cambridge University Press.

Kluger, A., \& DeNisi, A. (1996). The effects of feedback interventions on performance: A historical review, a meta-analysis, and a preliminary feedback intervention theory. Psychological Bulletin, 119(2), 254-284. http://dx.doi.org/10.1037/0033-2909.119.2.254

Kochanek, J. (2005). Building trust for better schools: Research-based practices. Thousand Oaks, CA: Corwin Press.

Kosfeld, M., Heinrichs, M., Zak, P., Fischbacher, U., \& Fehr, E. (2005). Oxytocin increases trust in humans. Nature, 435, 673-676.

Lajoie, S. (2008). Metacognition, self-regulation, and self-regulated learning: A rose by any other name? Educational Psychology Review, 20(4), 469-475. http://dx.doi.org/10.1007/s10648-008-9088-1

Lee, S. (2005, October). Relations between students' trust in teachers and the school effects in secondary school. Paper presented at the quarterly meeting of the Korean Educational Psychology Association, Pusan, Korea.

Leighton, J. P. (2009). Can you learn how to learn for life? Components from expert learning research. Journal of Applied Research on Learning, 2, 21-14.

Leighton, J. P., \& Bustos Gomez, M.C. (2014, April). Using the LEAFF model to enhance classroom learning and assessment. Paper presented at the annual meeting of the National Council on Measurement in Education (NCME), Philadelphia, PA.

Leighton, J. P., Chu, M.-W., \& Seitz, P. (2013). Cognitive diagnostic assessment and the learning errors and formative feedback (LEAFF) model. In R. Lissitz (Ed.), Informing the practice of teaching using formative and interim assessment: A systems approach (pp. 183-207). Charlotte, NC: Information Age Publishing.

Leighton, J. P., \& Gierl, M. J. (Eds.). (2007). Cognitive diagnostic assessment for education. Theory and applications. Cambridge, MA: Cambridge University Press. http://dx.doi.org/10.1017/CBO9780511611186

Leighton, J.P., \& Gierl, M.J. (2011). The learning sciences in educational assessment. Cambridge, MA: Cambridge University Press. http://dx.doi.org/10.1017/CBO9780511996276

Leighton, J. P., \& Sternberg, R. J. (2012). Reasoning and problem solving. In A. Healy \& R. Proctor (Eds.), Handbook of psychology: Vol. 4. Experimental psychology (2nd ed., pp. 631-659). New York, NY: Wiley. http://dx.doi.org/10.1002/9781118133880.hop204023

Limas, J.R. (2003). Small group dynamics in a nutshell. Manage, 1(4), 3-5.

Louis, K. (2008). Creating and sustaining professional communities. In A. M. Blankstein, P. D. Houston, \& R. W. Cole (Eds.), Sustaining professional learning communities (pp. 41-57). Thousand Oaks, CA: Corwin Press.

Maeroff, G. (1993). Building teams to rebuild schools. Phi Delta Kappan, 74(7), 512-519.

Maister, D., Green, C., \& Galford, R. (2000). The trusted advisor. New York, NY: The Free Press.

Mayer, R., \& Davis, J. (1999). The effect of the performance appraisal system on trust for management: A field quasi-experiment. Journal of Applied Psychology, 84(1), 123-136. http://dx.doi.org/10.1037/0021$\underline{9010.84 .1 .123}$

Mayer, R., Davis, J., \& Schoorman, F. (1995). An integrative model of organizational trust. Academy of Management Review, 20(3), 709-734.

Meier, D. (1995). The power of their ideas: Lessons for America from a small school in Harlem. Boston, MA: Beacon Press.

Meier, D. (2002). In schools we trust. Boston, MA: Beacon Press.

Misztal, B. (1996). Trust in modern societies. Cambridge, United Kingdom: Polity Press.

Moore, B. (2009). Emotional intelligence for school administrators: A priority for school reform? American Secondary Education, 37(3), 20-28.

Parsons, T. (1960). Structure and process in modern societies. Glencoe, IL: Free Press.

Rosen, R., \& Brown, P. (1996). Leading people: Transforming business from the inside out. New York, NY: Viking. 
Rotter, J. (1967). A new scale for the measurement of interpersonal trust. Journal of Personality, 35(4), 651665. http://dx.doi.org/10.1111/j.1467-6494.1967.tb01454.x

Rotter, J. (1980). Interpersonal trust, trustworthiness, and gullibility. American Psychologist, 35(1), 1-7. http://dx.doi.org/10.1037/0003-066X.35.1.1

Royal, M., \& Rossi, J. (1997). Schools as communities. Seattle, WA: ERIC Clearinghouse on Educational Administration.

Schoorman, F. D., Mayer, R. C., \& Davis, J. H. (2007). An integrative model of organizational trust: Past, present and future. Academy of Management Review, 32(2), 344-354. http://dx.doi.org/10.5465/AMR.2007.24348410

Sebring, P., \& Bryk, A. (2000). School leadership and the bottom line in Chicago. Phi Delta Kappan, 81(6), 440-443.

Sergiovanni, T. (1992). Moral leadership: Getting to the heart of school improvement. San Francisco, CA: Jossey-Bass.

Shute, V. (2008). Focus on formative feedback. Review of Educational Research, 78, 153-189. http://dx.doi.org/10.3102/0034654307313795

Simpson, J. (2007). Psychological foundations of trust. Current Direction in Psychological Science, 16(5), 264268. http://dx.doi.org/10.1111/j.1467-8721.2007.00517.x

Thweatt, K., \& McCroskey, J. (1998). The impact of teacher immediacy and misbehaviors on teacher credibility. Communication Education, 47(4), 348-358. http://dx.doi.org/10.1080/03634529809379141

Trust. (n.d.). In Merriam-Webster. http://www.merriam-webster.com/dictionary/trust

Tschannen-Moran, M. (2004). Trust matters: Leadership for successful schools. San Francisco, CA: JosseyBass.

Tschannen-Moran, M., \& Hoy, W. (1997). Trust in schools: A conceptual and empirical analysis. Journal of Educational Administration, 36(4), 334-352. http://dx.doi.org/10.1108/09578239810211518

Tschannen-Moran, M., \& Hoy, W. (2000). A multidisciplinary analysis of the nature, meaning, and measurement of trust. Review of Educational Research, 70(4), 547-593.

http://dx.doi.org/10.3102/00346543070004547

Watson, M., \& Ecken, L. (2003). Learning to trust: Transforming difficult elementary classrooms through developmental discipline. San Francisco, CA: Jossey-Bass. 